\title{
A methodological proposal for the analysis of Cladocera (Crustacea, Branchiopoda) subfossils from sediments of temporary aquatic ecosystems
}

\author{
E. E. Silva ${ }^{a *}$ (D), R. Cassino $^{b}$ (D), Z. W. Leibowitz ${ }^{a}$ (D) and E. M. Eskinazi-Sant'Anna ${ }^{a}$ \\ a'Laboratório de Ecologia Aquática, Conservação e Evolução, Universidade Federal de Ouro Preto - UFOP, \\ Campus Morro do Cruzeiro, s/n, Ouro Preto, MG, Brasil \\ bLaboratório de Paleontologia, Departamento de Geologia, Universidade Federal de Ouro Preto - UFOP, \\ Campus Morro do Cruzeiro, s/n, Ouro Preto, MG, Brasil \\ *e-mail: eskinazi.eneida@gmail.com
}

Received: February 26, 2018 - Accepted: May 4, 2018 - Distributed: February 28, 2020

(With 4 figures)

\begin{abstract}
The main objective of the present study was to promote some adaptations to the standard methodology used in the analysis of Cladocera subfossils. The samples used in this study were collected at Lagoa dos Coutos, a temporary lake located on an outcrop with iron-rich duricrust in the Serra do Gandarela (Minas Gerais, Brazil). The sediment from this pond, typical of temporary ecosystems in the region, is characterized by rigid concretions that are difficult to dissolve in aqueous media, making it difficult to visualize and analyze subfossils taxa. Sediment samples were prepared according to the standard methodology used in paleolimological studies and the methodological adaptations proposed in the present study, which included the addition of $1 \mathrm{mg}$ of Kochia scoparia, a palynological marker used to estimate subfossil density, as well as the addition of hydrofluoric acid (HF) to oxidize silicate materials. The samples prepared according to the new methodological procedure improved Cladocera subfossil visualization, facilitating the taxonomic analysis of the species. The samples submitted to the standard methodological procedure had a significantly higher mean of sediment particles (mean of 84.2 sediment particles) and $70 \%$ more residues compared to the samples prepared with the newly proposed methodology (mean of 22.1 sediment particles). Absolute data on the temporal variation of the density of Cladocera subfossils was obtained by using the palinological marker K. scoparia, which showed higher densities of subfossils in more recent, humid periods (112,000 subfossils/cm 3 at $5 \mathrm{~cm}$, equivalent to 3,500 years BP). The results indicate that the new methodology can contribute to advances in paleolimnological studies of temporary aquatic ecosystems, whose lake histories are rarely investigated, despite their ecological relevance as ecosystems that indicate environmental and climatic changes.
\end{abstract}

Keywords: paleolimnology, cladocerans, subfossils, temporary lake, methodology.

\section{Uma proposta metodológica para a análise de subfósseis de Cladocera (Crustacea, Branchiopoda) de sedimentos de ecossistemas aquáticos temporários}

\section{Resumo}

O principal objetivo do presente estudo foi promover algumas adaptações na metodologia padrão utilizadas para a análise de subfósseis de Cladocera. As amostras utilizadas nessa pesquisa foram coletadas na Lagoa dos Coutos, uma lagoa temporária encontrada em solo de afloramento ferruginoso na Serra do Gandarela (Minas Gerais, Brasil). O sedimento desta lagoa, típico de ecossistemas temporários da região, caracteriza-se por apresentar concreções rígidas de difícil dissolução em meio aquoso, que dificultam a visualização e análise taxonômica dos subfósseis. Amostras de sedimento foram preparadas de acordo com a metodologia padrão utilizada em estudos paleolimnológicos e as adaptações metodológicas propostas no presente estudo, que incluíram a adição de $1 \mathrm{mg}$ de Kochia scoparia, um marcador palinológico utilizado para estimar a densidade de subfósseis, além da adição de ácido fluorídrico (HF) para oxidação de materiais silicáticos. As amostras preparadas de acordo com o novo procedimento metodológico apresentaram melhor visualização dos subfósseis de Cladocera, facilitando a análise taxonômica das espécies. As amostras submetidas ao procedimento metodológico padrão apresentaram uma média significativamente maior de partículas de sedimentos (média de 84,2 partículas de sedimento) e $70 \%$ mais resíduos em comparação com as amostras preparadas com a nova metodologia proposta (média de 22,1 partículas de sedimento). Dados absolutos sobre a variação temporal da densidade dos subfósseis de Cladocera foram obtidos a partir do uso do marcador palinológico K. scoparia, revelando densidades 
mais elevadas de subfósseis nos períodos recentes ( 112.000 subfósseis $/ \mathrm{cm}^{3}$ nos $5 \mathrm{~cm}$ iniciais, equivalentes a 3.500 anos BP). Os resultados obtidos indicam que a nova metodologia pode contribuir para avanços em estudos paleolimnológicos de ecossistemas aquáticos temporários, raramente contemplados na reconstrução da história de lagos, apesar de sua relevância ecológica como ecossistemas sinalizadores de mudanças ambientais e climáticas.

Palavras Chaves: paleolimnologia, cladóceros, subfósseis, lagoa temporária, metodologia.

\section{Introduction}

Paleolimnological studies are essential to analyze temporal evolution of aquatic ecosystems, changes in biodiversity and the influence global events have on aquatic ecosystem processes. In general, lake sediments are excellent integrators of the aquatic communities' dynamics, and therefore regarded as refined testimonies of whole-lake changes (Gregory-Eaves and Beisner, 2011). The paleolimnological approach has recently become an important aid for aquatic ecosystem conservation decision making, utilizing past and present conditions to support new guidelines in terms of habitat quality and predisturbance conditions (Battarbee and Bennion, 2011).

The effectiveness of cladoceran subfossils as paleolimnological indicators is established in many studies. They have been used to elucidate species complexity, global climate changes as well as processes related to temporal dynamics of lakes such as predation effects, cultural eutrophication and acidification, among others (Amsinck et al., 2007; Jeppesen et al., 2001; Kamenik et al., 2007; Nevalainen et al., 2012; Rautio et al., 2000).

In the ferruginous geosystems of Quadrilátero Ferrífero of Minas Gerais (Southeastern Brazil), the presence of temporary ponds and the formation of ephemeral shallow lakes are frequents. In this region, the lake substrate consists of banded iron formations, mainly originated in the Eon Archean (4.6 - 2.5 Ga) and in the Eon Proterozoico (2.5 Ga to $1.6 \mathrm{Ma})$. These ferruginous concretions, which contain at least $15 \%$ of iron, are highly resistant to weathering, becoming an impermeable shell upon desiccation (Carmo and Kamino, 2015). These sedimentological traits make the extraction and analysis of zooplanktonic subfossils difficult, and this is why we propose a methodological adaptation to improve analysis and visualization of the cladoceran subfossils. We believe that the improvements obtained after the adaptations may be useful in future paleolimnological studies, especially those performed in temporary aquatic ecosystem sediments subjected to long desiccation periods.

\section{Methods}

Coutos Lake (1959'6.54' S; 433' $\left.4.75^{\prime \prime} \mathrm{W}\right)$ is an intermittent shallow temporary lake located in an ironstone outcrop area of Serra do Gandarela Mountains (Minas Gerais State, Brazil, at 1072 m.a.s.l.). The lake has an average depth of $0.65 \mathrm{~cm}$, reaching $1.5 \mathrm{~m}$ during the rainy season. During the dry period the lake may stay up to 7 months without any water. Coutos Lake is representative of the harshest conditions of dryness. This shallow lake is located on an outcrop with iron-ruch duricrust, under severe edapho-climatic conditions, including high ultraviolet (UV) intensities and daily temperature variations of the substrate that can easily exceed $50{ }^{\circ} \mathrm{C}$ (Jacobi and Carmo, 2008).

A sediment core was collected with a $15 \mathrm{~cm}$ diameter, $25 \mathrm{~cm}$ long PVC pipe, in the center of the lake (called P1). This core was then retrieved, sealed with Parafilm ${ }^{\circledR}$ and plastic wrap, kept in a cooler at $8{ }^{\circ} \mathrm{C}$ and brought back to the Laboratory of Aquatic Ecology at the Federal University of Ouro Preto and kept in the freezer at $-4{ }^{\circ} \mathrm{C}$ until processing. After thawing, the core was opened on opposing sides using a Dremel 3000 rotary saw. Thereafter, the cores were separated into two halves and superficially scraped with a plastic knife to prevent cross layer contamination (Leibowitz, 2016). The core was then cut in 1-cm sections for the first $10 \mathrm{~cm}$ (P1C4-1 through P1C4-10). Each 1-cm sample was then placed in a petri dish and weighed on a Shimadzu AY220 analytical scale. Subsequently each sub-sample was put in an oven $<40{ }^{\circ} \mathrm{C}$ until a constant weight was achieved ( 48 hours). The sub-samples were then homogenized and quartered. Samples at 5 and $10-\mathrm{cm}$ of each core, were sent to Beta Analytic (Florida, USA) for carbon dating. CALIB (Stuiver and Reimer 1993) was used along with the most recent southern hemispheric calibration set to calibrate and interpolate $14 \mathrm{C}$ dates, which revealed a time resolution of approximately 320 years in the superficial centimeter and 5450 years in $10 \mathrm{~cm}$

Sediment subsamples were analyzed according to two tested methodologies: the Korhola and Rautio (2001), Szeroczyska and Sarmaja-Korjonen (2007) usual methodologies and the adapted method in this study. In the standard methodology, $1 \mathrm{~cm}^{3}$ sedimentary portions were submerged in a $10 \%$ potassium hydroxide solution $(\mathrm{KOH})$, heated to $80^{\circ} \mathrm{C}$ in a water bath and manually homogenized manually for 30 minutes. After this stage, the material was rinsed with distilled water and filtered in $50 \mu \mathrm{m}$ opening mesh. The remaining sediment was centrifuged (3000 rpm for $10 \mathrm{~min}$ ) and used in the preparation of permanent slides with glycerin gelatin and analyzed via optical microscopy.

In the proposed methodology $1 \mathrm{~cm}^{3}$ portions of the sediment were used, spiked with $1 \mathrm{mg}$ of the palynological marker Kochia scoparia. The addition of this marker allows us to determine more clearly the subfossils concentration in the sediment (number of subfossils $/ \mathrm{cm}^{3}$ ), because $1 \mathrm{mg}$ of the palynological marker contains about 60,500 grains (Salgado-Labouriau and Rull, 1986). The subsamples were then submerged in a $10 \%$ potassium hydroxide solution for 1 hour, heated to $80^{\circ} \mathrm{C}$ in water bath and manually homogenized for 60 minutes. Next, the material was rinsed with distilled water and filtered in a $30 \mu \mathrm{m}$ opening mesh and placed in hydrofluoric acid solution (HF) for 24 hours for oxidation of silicate materials that make it difficult to 
visualize the subfossils. After this step, the sediment was filtered in a $30 \mu \mathrm{m}$ opening mesh size to reduce the loss of subfossil structures. Subsequently they were mounted on permanent slides for optical microscopy (Figure 1).

Three permanent slides were analyzed for the subfossils counting, which were prepared according to the two tested methodologies. At least 10 optical fields were used for each slide and a minimum of 100 subfossil parts of Cladocera exoskeleton (carapaces, head shields, post abdomen, in addition to ephippials) were counted under an optical microscope. The taxonomical identification of the subfossils followed Elmoor-Loureiro (1997) identification description key. The counting of the material in the slides took into consideration, besides the Cladocera subfossils, the sediment residues in the sample.

The determination of the number of zooplanktonic subfossils in the sample (number of subfossils $/ \mathrm{cm}^{3}$ ) was performed using the following formula:

Number of zooplankton microfossils $\times$ $=\frac{\text { Number of K.scoparia marker }(60,500 \text { grains })}{\text { Number of K.scoparia grains in the final sample }}$

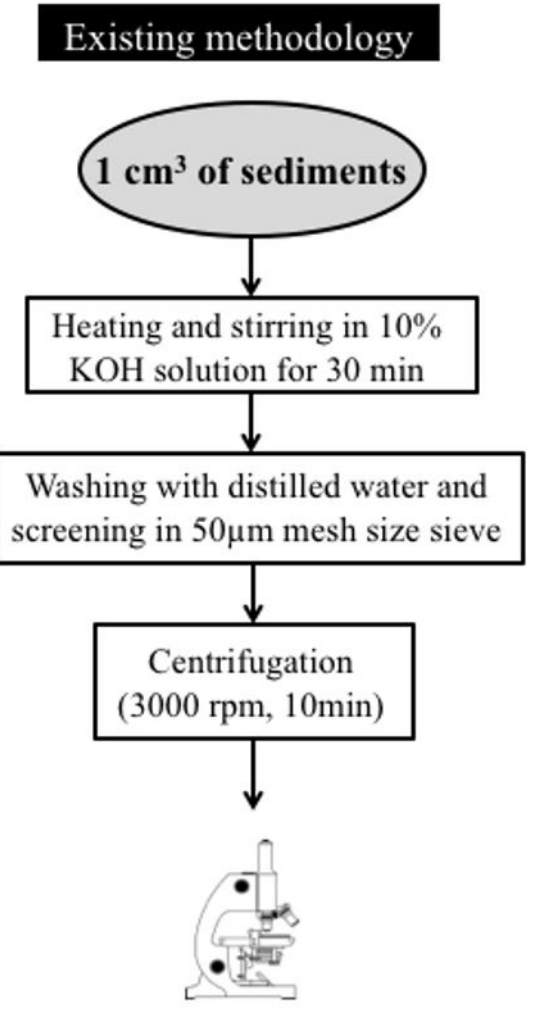

After the counting, the results of the samples prepared with different methodologies were analyzed in an unpaired t-test, preceded by Kolmogorov-Smirnoff test.

\section{Results and Discussion}

Analyzing the two methodological preparations related to the presence of sediment fragments in the final samples, a statistically significant difference was obtained between the two sets of samples (usual and adapted methodology). In the usual method the sediment particle average in the final sub-samples was significantly higher (ca. 70\% more particles and median of 84.2 of sediment particles) than the average found in the sub-samples submitted to the new methodological procedure (less than $40 \%$, averaging 22.1 sediment particles) (Test-t, $\mathrm{p}<0.0001$; gl 12.63) (Figure 2). From the qualitative point of view, the difference between the sub-samples prepared with distinctive methodologies is clearly visible by observing Figure 3. The sub-samples submitted to the proposed procedure showed lower presence of sediment residues, facilitating the location, identification and morphometric measure taking of the subfossils.

\section{Proposed methodology}

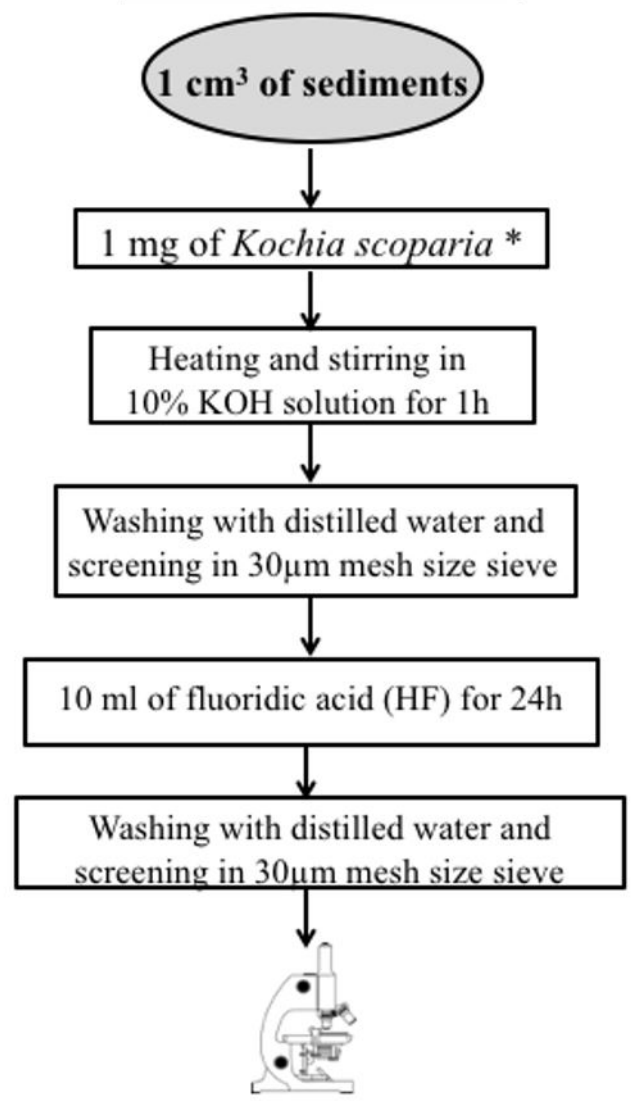

Figure 1. Representative diagram comparing the standard methodology and the proposed methodology. *Palinological polen exotic marker. 
The determination of the zooplanktonic subfossil density in the sediment (number of subfossils $/ \mathrm{cm}^{3}$ ) is not a traditional approach in paleolimnology, however it enables the researcher to produce absolute data as opposed to merely

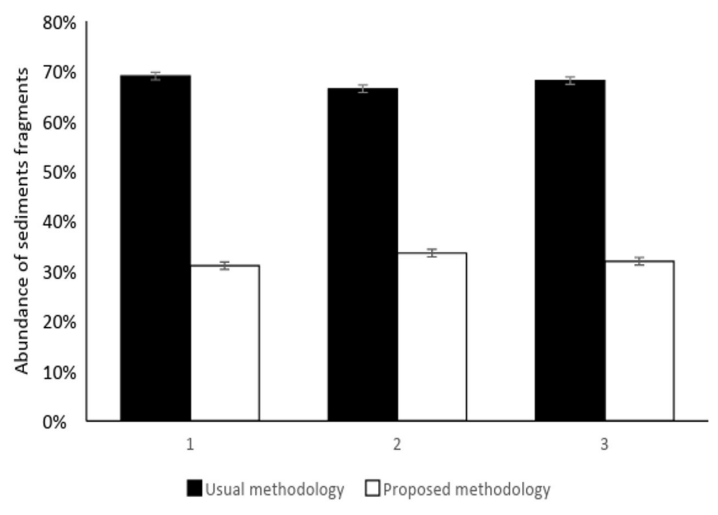

Figure 2. Abundance (\%) of sediment residues between sub-samples prepared according to usual and proposed methodology. relative data. The obtained results in the present study suggest that the use of the K. scoparia palynological marker may constitute a satisfactory approach to the determination of zooplanktonic subfossil density, because the development of a specific marker for studies with cladoceran subfossils has not been elaborated. The results indicate a prominent temporal variation of the zooplanktonic subfossils in Lake Coutos, with generally higher densities (maximum of 112.000 subfossils $\left./ \mathrm{cm}^{3}\right)$ in more recent period $(5 \mathrm{~cm}$, equivalent to 3,500 BP) (Figure 4).

Paleolimnological reconstructions of lakes are an essential tool for lake ecology, management and conservation (Brugam and Speziale, 1983). Considering the extreme shortage of paleolimnological studies in Latin America and the great diversity of temporary aquatic ecosystems (rivers, lakes, lagoons and reservoirs) that represent important environmental sites for the understanding of aquatic ecosystems temporal evolution, we believe that the proposed methodology may make it easier for the development of new studies and techniques that provide advances in the paleolimnological approaches of temporary aquatic ecosystems in Brazil.

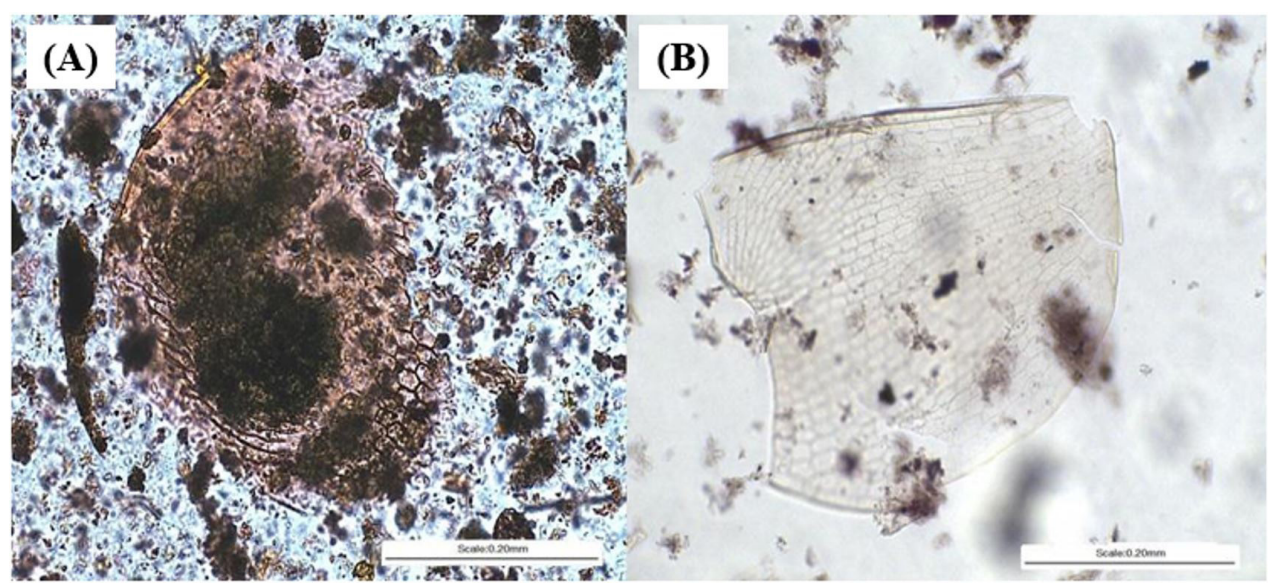

Figure 3. General aspect of the sub-sample in optical microscopy. (A) sediment preparation with the usual method and (B) sediment preparation using the proposed method.

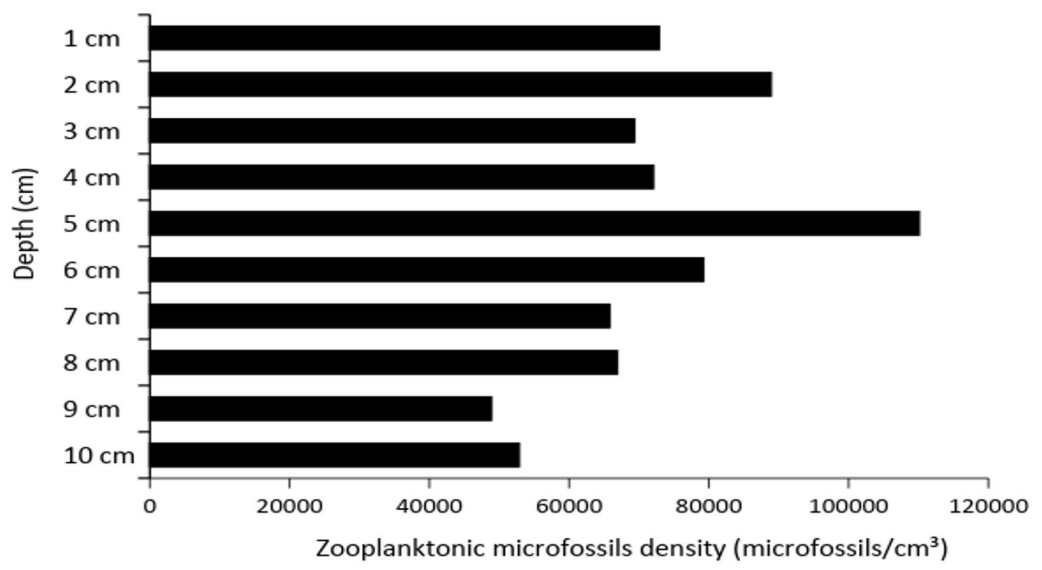

Figure 4. Vertical variation of the zooplanktonic subfossils density $\left(\mathrm{cm} /{ }^{3}\right)$ in the Coutos Lake. 


\section{Acknowledgements}

Graduate fellowships were granted to EES and ZWL from the Coordination for the Improvement of Higher Education Personnel (CAPES). This study was supported by the Foundation for Research Support of Minas Gerais State (FAPEMIG; Project CRA-APQ 01767-11). We thank the anonymous referee for comments that substantially improved the manuscript.

\section{References}

AMSINCK, S.L., JEPPESEN, E. and VERSCHUREN, D., 2007. Use of Cladoceran resting eggs to trace climate-driven and anthropogenic changes in aquatic ecosystems. Diapause in Aquatic Invertebrates Theory and Human Use, vol. 84, pp 135157. http://dx.doi.org/10.1007/978-1-4020-5680-2_8.

BATTARBEE, R.W. and BENNION, H., 2011. Palaeolimnology and its developing role in assessing the history and extent of human impact on lake ecosystems. Journal of Paleolimnology, vol. 45, no. 4, pp. 399-404. http://dx.doi.org/10.1007/s10933-010-9423-7.

BRUGAM, R.B. and SPEZIALE, B.J., 1983. Human disturbance and the paleolimnological record of change in the zooplankton community of Lake Harriet, Minnesota. Ecology, vol. 64, no. 3, pp. 578-591. http://dx.doi.org/10.2307/1939977.

CARMO, F.F. and KAMINO, L.H. 2015. Geossistemas Ferruginosos do Brasil: áreas prioritárias para conservação da diversidade geológica e biológica, patrimônio cultural e serviços ambientais. Belo Horizonte: Inst. Prístino, 553 p.

ELMOOR-LOUREIRO, L.M.A. 1997. Manual de identificação de cladóceros límnicos do Brasil. Brasília: Editora Universa 156p.

GREGORY-EAVES, I. and BEISNER, B.E., 2011. Palaeolimnological insights for biodiversity science: an emerging field. Freshwater Biology, vol. 56, no. 12, pp. 2653-2661. http:// dx.doi.org/10.1111/j.1365-2427.2011.02677.x.

JACOBI, C.M. and CARMO, F.F., 2008. Diversidade dos campos rupestres ferruginosos no Quadrilátero Ferrífero, MG. Megadiversidade, vol. 4, pp. 24-32.

JEPPESEN, E., LEAVITT, P., DE MEESTER, L. and JENSEN, J.P., 2001. Functional ecology and palaeolimnology: using cladoceran remains to reconstruct anthropogenic impact. Trends in Ecology \& Evolution, vol. 16, no. 4, pp. 191-198. http://dx.doi. org/10.1016/S0169-5347(01)02100-0. PMid:11245942.

KAMENIK, C., SZEROCZYŃSKA, K. and SCHMIDT, R., 2007. Relationships among recent Alpine Cladocera remains and their environment: Implications for climate-change studies. Hydrobiologia, vol. 594, no. 1, pp. 33-46. http://dx.doi.org/10.1007/ s10750-007-9083-4.

KORHOLA, A. and RAUTIO, M., 2001. Cladocera and other branchiopod crustaceans. In: J.P. SMOL, H.J.B. BIRKS, W.M. LAST, eds. Tracking Environmental change using lake sediments. Dordrecht: Springer, vol. 4, pp. 5-41. http://dx.doi.org/10.1007/0306-47671-1_2.

LEIBOWITZ, Z.W. 2016. Diatoms as Proxies for Environmental Change: a Paleolimnological Investigation of a Shallow Iron Outcrop Lake (Lagoa dos Coutos, Serra do Gandarela, MG). Ouro Preto: Universidade Federal de Ouro Preto, 98 p. Dissertação de Mestrado em Ecologia de Biomas Tropicais, Instituto de Ciências Exatas e Biológicas.

NEVALAINEN, L., LUOTO, T.P., KULTTI, S. and SARMAJAKORJONEN, K., 2012. Do subfossil Cladocera and chydorid ephippia disentangle Holocene climate trends? The Holocene, vol. 22, no. 3, pp. 291-299. http://dx.doi.org/10.1177/0959683611423691.

RAUTIO, M., SORVARI, S. and KORHOLA, A., 2000. Diatom and crustacean zooplankton communities, their seasonal variability and representation in the sediments of subarctic Lake Saanajärvi. Journal of Limnology, vol. 59, no. 1s, pp. 81-96. http://dx.doi. org/10.4081/jlimnol.2000.s1.81.

SALGADO-LABOURIAU, M.L. and RULL, V., 1986. A method of introducing exotic pollen for paleoecological analysis of sediments. Review of Palaeobotany and Palynology, vol. 47, no. 1-2, pp. 97-103. http://dx.doi.org/10.1016/0034-6667(86)90008-4.

STUIVER, M. and REIMER, J., 1993. Extended 14C data base and revised CALIB 3.0 14C age calibration program. Radiocarbon, vol. 35, no. 01, pp. 215-230. http://dx.doi.org/10.1017/ S0033822200013904.

SZEROCZYSKA, K. and SARMAJA-KORJONEN, K. 2007. Atlas of Subfossil Cladocera from Central and Northern Europe. Świecie: Friends of the Lower Vistula Society. 